NBER WORKING PAPER SERIES

\title{
INSTITUTIONAL AND NON-INSTITUTIONAL EXPLANATIONS OF ECONOMIC DIFFERENCES
}

\author{
Stanley L. Engerman \\ Kenneth L. Sokoloff \\ Working Paper 9989 \\ http://www.nber.org/papers/w9989 \\ NATIONAL BUREAU OF ECONOMIC RESEARCH \\ 1050 Massachusetts Avenue \\ Cambridge, MA 02138 \\ September 2003
}

We would like to express deep appreciation for the research assistance of Elisa Mariscal, Patricia Juarez, and Luis Zegarra. We have also benefited from discussions with Daron Acemoglu, Lance Davis, David Dollar, David Eltis, Jeff Frieden, Avner Greif, Stephen Haber, Karla Hoff, Daniel Kaufmann, Zorina Khan, Naomi Lamoreaux, Frank Lewis, Peter Lindert, John Majewski, Douglass North, James Robinson, Jean-Laurent Rosenthal, Mary Shirley, Joel Slemrod, Peter Temin, John Wallis, and Jeffrey Williamson. We gratefully acknowledge the financial support we have received from the National Science Foundation, as well as from the Academic Senate at the University of California, Los Angeles. The views expressed herein are those of the authors and are not necessarily those of the National Bureau of Economic Research.

(C)2003 by Stanley L. Engerman and Kenneth L. Sokoloff. All rights reserved. Short sections of text, not to exceed two paragraphs, may be quoted without explicit permission provided that full credit, including (C) notice, is given to the source. 
Institutional and Non-Institutional Explanations of Economic Differences

Stanley L. Engerman and Kenneth L Sokoloff

NBER Working Paper No. 9989

September 2003

JEL No. N10

\begin{abstract}
Although we cannot conceive of processes of economic growth that do not involve institutional change, in this essay we outline some reasons why one should be cautious about grounding a theory of growth on institutions. We emphasize how very different institutional structures have often been found to be reasonable substitutes for each other, both in dissimilar as well as similar contexts. The historical record, therefore, does not seem to support the notion that any particular institution, narrowly defined, is indispensable for growth. Moreover, we discuss how the evidence that there are systematic patterns to the ways institutions evolve undercuts the idea that exogenous change in institutions is what powers growth. Institutions matter, but our thinking of how they matter should recognize that they are profoundly influenced by the political and economic environment, and that if any aspect of institutions is crucial for growth, it is that institutions change over time as circumstances change.
\end{abstract}

Stanley L. Engerman

Department of Economics

University of Rochester

Rochester, NY 14627

and NBER

enge@troi.cc.rochester.edu

Kenneth L. Sokoloff

Department of Economics

U.C.L.A

Los Angeles, CA 90095-1477

and NBER

sokoloff@ucla.edu 
Economists have long been concerned with the explanation of differences across countries in levels of national income, population, and per capita incomes, as well as in their rates of growth. Because many of the processes of economic development are presumed to operate over long periods of time, those studying the sources of these differences have quite naturally turned to the historical record for relevant evidence. Their concern with economic history thus comes not only from a desire to achieve a better understanding of the past, but also from by a belief that such knowledge can serve as a guide for policymakers striving to improve the economic and social conditions of currently less developed nations. Many scholars have set about making contributions to knowledge through detailed investigations of the processes of growth in individual countries. Others have sought to discern what factors were crucial through comparative studies, focusing on issues such as why nations differed with regard to the timing of the onset of growth or how and why their records of achieved rates of growth varied over a long period of time.

Recently considerable attention has been given to the question of why European nations and some of their overseas offshoots expanded more rapidly than did the economies of Asia, Africa, and Latin America after the eighteenth century, either generating new gaps in levels of income and rates of growth, or else greatly widening whatever differentials may have previously existed (see Table 1). ${ }^{1}$ Previously the principal focus of historians examining the basis for differences in long-term economic performance had been with what led Great Britain to accomplish an Industrial Revolution sometime after the middle of the eighteenth century, and ahead of its European rivals (see Table 2). ${ }^{2}$ Given the greater similarity of economic, political, and social structures 
among the European nations than those between Europe and the rest of the world, the factors highlighted in the discussions of the development of the Industrial Revolution are rather different from those generally featured in the broader geographic comparisons. In both cases, however, what the economists and economic historians are seeking to explain is why some nations in today's world remain poor, relatively and absolutely, and what conditions can be changed in order to achieve success in spurring growth and improving the welfare of the respective populations. It is this problem that the recent study of institutions has sought to help resolve and that probably represents its most significant contribution.

It is not necessary here to attempt to catalogue the full set of explanations that have been given for differences in economic development, since many books and articles, published and forthcoming, have already done that. For present purposes, however, we highlight a transition over the last few decades from a concentration on the role of narrowly-defined economic factors to a focus on the significance of various social structures and culture in providing the conditions conducive to economic development. ${ }^{3}$ Arguments based on conditions such as favorable natural resources (including accessible coal and iron, in the case of Britain), high rates of capital formation, and extensive markets or other circumstances that encourage a faster pace of technological change, which had long been central to our understanding of why some economies enjoyed better performance, have been replaced (or supplemented) by arguments concerned with how differences across societies in political and cultural institutions arose, and how they influence the processes of growth. ${ }^{4} \quad$ Although we cannot conceive of processes of economic growth that do not involve institutional change, in this essay we outline some 
reasons why one should be cautious about grounding a theory of growth on institutions. We emphasize how very different institutional structures have often been found to be reasonable substitutes for each other, both in dissimilar as well as similar contexts. The historical record, therefore, does not seem to support the notion that any particular institution, narrowly defined, is indispensable for growth. Moreover, we discuss how the evidence that there are systematic patterns to the ways institutions evolve undercuts the idea that exogenous change in institutions is what powers growth. Institutions matter, but our thinking of how they matter should recognize that they are profoundly influenced by the political and economic environment, and that if any aspect of institutions is crucial for growth, it is that institutions must change over time as circumstances change.

\section{II.}

A basic categorization of explanations for economic growth would include economic, cultural, political, and institutional factors. The import of economic factors was much discussed in the ancient world, and amongst the numerous economic factors that have been considered since that time are: natural resources, such as the supplies of coal and iron; the opportunity to trade at low cost with other regions or nations, which provides markets that encourage specialization in producing goods in which the economy has a comparative advantage (and perhaps stimulating more rapid technical progress) as well as serves as a source of imports that a nation may be incapable of producing; climate, which can influence productivity through a variety of mechanisms; colonial empire, which might be associated with especially high private or social returns to investment; and the role of population change. Some contend, for example, that rapid 
population growth has sometimes proved beneficial, fostering lower labor costs or the advantages in scale effects that come from higher total demand; others argue for the benefits of relatively slow growth in population, on the grounds that lower population density encourages higher per capita incomes and higher rates of capital formation. These, and other so-called economic explanations, say little explicitly about noneconomic factors and institutions, although this does not mean that the latter are not implicit in the analysis.

Discussions of the role of non-economic factors (encompassing the cultural, political, and institutional) in accounting for differences across societies in economic development can also be traced back many centuries. Several of the classic theories for the rise of European capitalism and the onset of modern economic growth are based on conditions that clearly fall outside of the conventional economic sphere, such as the spread of particular religious beliefs, be it the Protestantism pointed to by Max Weber, the Judaism highlighted by Werner Sombart, or shifts in the orientation of dominant religions. ${ }^{5}$ Other arguments stress the important contributions of the advance of scientific and rational thought, or the impact of changing tastes for consumer goods and the effects on choices between work and leisure on the supply and intensity of labor during early industrialization. ${ }^{6}$ Changes in legal systems, in degrees of trust and the extent of social capital, and in the nature of political organization and the extent of democracy, have more recently been advocated as critical factors explaining differentials or shifts in economic performance. ${ }^{7}$ Although changes in these kinds of circumstances, such as in religion, are generally treated as exogenous to the economy, the nature of the interaction between economic and so-called "non-economic" factors may be complex. The contrast in views 
between Weber and of R.H. Tawney on the relationship between religious changes and the rise of capitalism in Britain, and in northern Europe more generally, for example, corresponds to similar debates over the sources of change in many other purportedly noneconomic conditions relevant to economic growth. ${ }^{8}$ Moreover, the implications of the very slow diffusion of cultural change (and of institutional change more generally) and economic growth around the world represent a puzzle for those who believe that introducing exogenous changes in these facets should have significant, favorable effects and constitute a viable instrument of economic policy. ${ }^{9}$

Quite a wide range of non-economic conditions relevant for growth have featured in the debates over why Britain was the first industrial nation. Many can be subsumed in the blanket category of culture, where cultural factors are understood to include: religion, particularly the impact of non-conformists in the development of technology and entrepreneurship in British economy; the scientific spirit and the expansion of knowledge, including a willingness to search out new methods and technologies; and the emergence of an educational system that permitted a wide diffusion of information and skills among the population. Culture has also been defined to include family and kinship patterns; tastes and preferences regarding work versus leisure; time preferences determining the levels of savings and consumption, and the development of a widespread desire to financially profit-maximize or pursue material gain more generally. Proponents of the view that cultural change was responsible for economic change generally point to their coincidence in 18th century Britain, and presume that culture consists of behaviors and values that are determined independently of economic factors. This may, however, be an artificial distinction, because the economic effects of cultural 
factors, if not the cultural beliefs themselves, are often greatly influenced by the relative costs of different patterns of behavior and the amounts of income that people are willing to forgo to obtain chosen ends. ${ }^{10}$

The recent work on the significance of institutions for understanding why Britain industrialized first, and for understanding differences in economic performance more generally, gives relatively little attention to the role of culture per se. In emphasizing property rights and other aspects of the British legal framework, it breaks sharply from the previous stream of work on institutions by economists who emphasized culture in treating the evolution of economies, as part of a critique of classical economic theory. ${ }^{11}$ Current thinking about institutions instead follows the pioneering approach of Douglass North in grounding the analysis of the causes and consequences of institutions and institutional change on theory. ${ }^{12}$ This perspective defines institutions, though difficult to do with precision, as encompassing the specific organizations or rules that constrain and influence human behavior. A key aspect of these humanly-devised rules is that they structure human actions by providing incentives that shape economic and political organization. Formal rules, plus the informal constraints that develop, influence the costs of production and of transaction within society. Among the institutions that are most important for economic performance are those involving the definition and enforcement of property rights, between the government and private parties and between the individuals within a society. The link between appropriate institutions and economic growth is that institutions reduce the costs of production and distribution, allowing private agents more scope to benefit from specialization, investment, and trade. Institutions, as human-imposed constraints, are not the only constraints that society or 
private actors confront, since there are others due to the state of technological knowledge, demographic forces, nature (including climate and topography), as well as other features of the environment that may also have implications for the patterns of economic activity. ${ }^{13}$

Institutions, as described, play several roles in the economy. They influence the beliefs and behaviors of individuals and groups, and thus the preferences and priorities expressed through both private and public decisions. Another important role of institutions is providing for efficient property rights, trust, and effective incentives, and thus facilitating the organization and conduct of appropriate and constructive transactions and interactions among individuals and firms. Indeed it is claimed, by North and others, that it was sound property rights and incentive schemes made possible by its distinctive institutions that were key to Britain industrializing first. ${ }^{14}$ No economic development is possible without secure property rights. The specification of formal rights is only one part of society's problem however. The nature of the enforcement of institutional provisions, both as to accepted legitimacy and effectiveness, is critical to the success of whatever institutions exist. Similarly, the nature of legislative decisions and judicial rulings will influence outcomes, whether or not consistent with the circumstances of the adoption of particular institutions. Enforcement is sometimes bilateral, between individuals, with no government role to ensure compliance, but in other cases enforcement requires governmental participation and action.

Although those who stress the importance of the institutional framework have somewhat different concerns than those who highlight the significance of culture, the two perspectives share an emphasis on the extent to which "non-economic" variables evolve 
independently of the processes of economic growth. Indeed, proponents of both views champion how the appreciation of this pattern, as well as of the impacts of those variables on the economy, constitute a salient intellectual advance over the earlier (circa 1950s through 1970s) literature on economic development, which focused primarily on economic variables, such as natural resources, physical capital, human capital (mainly education), exchange rates, and technical change. That generation of economists certainly accepted the importance of institutions, culture, or political stability, but presumed either that the appropriate institutions and beliefs existed already, or else that they would evolve in constructive directions relatively easily when the economic factors that could generate economic growth were in place. Since economic forces obviously do not operate in a vacuum, it may have been difficult for them to conceive of a noninstitutional interpretation of economic growth.

Even as a purely logical construct, a wholly non-institutional (or anti-institutional) explanation of economic growth seems implausible (as would an explanation that takes no account of real economic factors), but as discussed below, debate on the relative importance of institutional and non-institutional forces has continued. ${ }^{15}$ The essential questions, thus, seem to us to be empirical. How much of the variation in economic performance over country and time can be attributed to differences in institutions, with pure economic factors constant or endogenous with respect to institutions, and how much is due to differences in the economic variables, with institutions constant or endogenous? What are the processes that govern the ways specific institutions evolve, and under what circumstances can the introduction of exogenous institutional changes be considered viable economic policies? 


\section{III.}

Although in principle these questions can be framed as empirical issues, it is far from easy to clearly distinguish between, or gauge the relative power of, the institutional and non-institutional explanations of economic differences. No one would claim that there is a general answer, and indeed few, if any, individual cases seem not to allow some role for each type of explanation. There has been considerable interest in recent years, however, in a manner of posing the problem that might appear to make the empirical work more tractable: are the key elements in determining institutions exogenous or endogenous? This distinction has been with us a long time, as in the debates over the superiority of British institutions, but has figured prominently in the study of how the various economies established as colonies by Europeans (or others) developed over time. Even in the absence of a substantial indigenous population in the area of settlement, the presence of one group in the colony, arriving from the metropolis, and another remaining in the metropolis, means that there were different circumstances for institutional development. In principle, therefore, a researcher could evaluate just how much of an impact the different circumstances had on the ways the institutions evolved. That many of the European countries established multiple colonies, in very different environments, further enhances the quality of the information arising from the natural experiment.

If the institutions in the colonies were, or remained, the same as those of the metropolitan nation (or perhaps the same as those of the indigenous societies that predated the arrival of the Europeans), they might be regarded as exogenous. In such a case, the institutions could be reasonably interpreted as evolving independently of the conditions in the respective colonial economies, and systematic patterns in subsequent 
differences in economic performance across the economies could, after controlling for the purely economic factors, be attributed to institutions. If, however, the institutions in the colony diverged in ways that could be explained as adaptations by the respective population to the different environment, natural or human, then it would support the view that institutions were endogenous with respect to circumstances. Because institutions are human-fashioned structures that presumably reflect the efforts of populations trying to make the best of the opportunities and problems they face, most observers would be surprised if they were not at least partially endogenous. Indeed, most scholars feel that the institutions that emerged across the colonies established by the Europeans do seem to have varied systematically with aspects of the environment such as climate, land type, and natural resources. Some would go even further and suggest that the direction of institutional change is often endogenous to the growth process, as changes in technology and in incomes generate changes in tastes, changes in the returns to organizing production and transactions in various ways, and changes in patterns of behavior more generally.

To acknowledge that there is some endogeneity to institutions does not imply that institutions are unimportant, or that they have only a limited impact on economic performance. Endogenous institutions, once in place, can prove as crucial as if they were exogenous, and they might persist for as long or even longer. The key difference between those who contend that institutions are exogenous and those who argue they are endogenous is not with their impact and influence, but instead with where institutions come from and with the extent to which they are -- or might be expected to -- be revised over time. 
It is widely recognized that it is sometimes useful to fix some types of institutions over time. Credible commitment to property rights is perhaps the classic example of the value of certainty about policy action. ${ }^{16}$ More generally, however, allowing some flexibility in institutions, such that they can be altered to make it easier for private or public agents to take fuller advantage of the new opportunities that arise as technology or the environment changes, would normally be expected to foster better economic performance and more rapid growth. Among the many such innovations in institutions that could be cited to illustrate the utility of institutions changing as conditions change are those underlying the modern patent system, those providing for public provision of education, those responsible for the organization of corporations where shareholders are protected because they have limited liability, and those responsible for the establishment of central or quasi-central banks such as the Federal Reserve or the Bank of England. Determining the optimum degree of flexibility in, and designing mechanisms well suited to respond constructively to ever-changing circumstances with institutional change, are complex issues. While some see the role of constitutional provisions as a means of ensuring stability in the decision-making process and institutions more generally, most constitutions do have provisions for amendments, and allow some degree of legislative and governmental flexibility in setting the legal structure. Allowance for modifications to the laws need not harm the potential for growth, nor even yield instability, particularly given that the voting and other costs of implementing changes are typically high. ${ }^{17}$ Indeed, there are likely more cases of how nations and economies suffered from inflexible institutions than from excessive flexibility. ${ }^{18}$ 
Perhaps the most important elements of institutional structures are those that ensure an ability to adapt to different conditions and to adjust to new circumstances as seems necessary, rather than those that entail the retention and maintenance of any specific set of policies. The capability for adaptation, based in part on the population's education and their political liberties, may ultimately be more significant for economic growth than the continuation of any particular set of beliefs, rules, or behavior. This was likely significant in the case of European expansion, where there was geographic movement to different environments, with new sorts of climates, soil types, natural resources, and economic problems to grapple with. As shall be discussed below, even if there were some specific cultural carryovers from Europe to the Americas, and these did play a role early in the settlement process, it is not clear that these factors were immutable or remained unchanged for long periods. The confrontation with a new environment that offered rich opportunities, but in unfamiliar contexts, led to some adaptations, adjustments, and innovations in institutions in the interests of economic improvement.

Another issue that is central to understanding how institutions matter for growth concerns the likelihood that no one particular narrowly-specified institution is required, as there are often alternative institutional forms or structures that are reasonable substitutes for each other and may achieve similar economic performance. Those who hold this view that non-optimal institutions may still be consistent with high rates of economic growth, though perhaps not the highest rate that was possible, often point to the stark contrasts across industrialized countries in the importance of banks relative to securities markets in financial intermediation, in the reliance on common or civil law, in 
how bankruptcy laws balance the rights of creditors and debtors, in systems and levels of taxation, and in the division of power between the executive, the legislature, and political party structures. These and many other examples, historical and contemporary, suggest the usefulness of institutions generally in helping societies take advantage of the opportunities the environment offers them, but support the idea that no single institutional solution is crucial. In this way, the role of institutions might be considered analogous to the role of technology, in that the processes of change are important but no single method of accomplishing a goal is indispensable. ${ }^{19}$

A perhaps more serious issue is that among the feasible set of institutional solutions to a general problem, different approaches may have different implications for different segments of the population. Depending upon the manner in which institutions evolve, or are designed, in a society, they may develop to favor the interests of more powerful groups at the expense of others, or even of the population at large. For example, elites might prefer policies that raise their share of national income, even if they reduce long-run rates of growth. The nature of the political power structure in society is critical in determining which institutions are adopted. The suffrage, or the distribution of political influence more generally, may be rather broad and inclusive, with a relatively large share of the population able to vote. ${ }^{20}$ Or, alternatively, the franchise may be limited, by requirements of literacy, wealth, nationality, age, and gender, with only a small minority of the population able to vote and to directly influence policy. When the suffrage is restricted, many members of society have only very limited political influence and no direct voice in establishing the institutional framework. Even a very small segment of the population, but one with highly disproportionate political power, would be 
able to establish institutions, legal codes, and property rights regimes that serve their own interests, and be able to exclude other members of society from benefits. ${ }^{21}$ Thus, there could well be a well- defined and enforced set of property rights, but one coincident with a large component of the population being outsiders to decision-making in society. ${ }^{22}$

Slave societies in the Americas often had well-defined institutions and property rights, and were capable of rapid economic growth, but part of their population had no rights and no means to obtain any. They provide a powerful example, albeit an extreme one, of how the determination of the size and nature of the elite groups, by political, economic, and/or military means, is critical to the establishment of institutions. Being excluded from voting does not necessarily mean a failure to benefit from economic change, nor that there will not be subsequent improvements in the rights to suffrage, but the limited nature of the decision-making group still raises important issues for our understanding of the distribution of rewards from economic activity. More generally, the observation that societies vary in how much influence different segments of the population can exert in shaping institutions implies that there may be systematic patterns in how flexible they are in adapting (or innovating) their institutions to enhance their the ability of their populations to take advantage of new opportunities created by changes in the environment.

\section{IV.}

To better understand the role of institutions in economic growth it will be useful to examine some historical examples in which different institutions have impacted on the economy. It is no doubt easier to isolate the effect of institutions if we believe that they are exogenously determined by the forces of past history or by forces outside of the 
current economy. Among the factors that have sometimes been suggested as playing this role are: externally generated changes in mentalité due to change in religious belief or secular attitudes; the outcome of a military conflict, either due to externally generated changes in the power structure or of internal revolutionary actions that altered the balance of political power; the non-military introduction of new foreign influence and contacts, reflecting, in part, improvements in transportation and communication; and, as shall be discussed in more detail below, the settling of new areas by people from a distant metropolis, whose institutions could be regarded as exogenous to the new area of settlement. In this context we consider non-institutional explanations to be not an absence of institutions (since that is not possible), but the presence of institutions regarded as endogenous to the socio-economic process, even when the circumstances giving rise to the institutions are themselves exogenous to the economy (as, e.g., climate and natural resources).

In evaluating whether institutions are endogenous, there are several approaches that could be taken. One concerns the impact of resources and natural and human endowments upon institutions. A number of scholars have recently argued that there were systematic patterns in the types of institutions that evolved as settlers in European colonies adjusted to conditions that differed from those of the metropolis in terms of disease environments and economic opportunities. ${ }^{23}$ Subjecting this notion to empirical testing is complicated by the enormous range of institutions that attention could be directed at, some of which reflect metropolitan carryovers, others of which developed very differently in the colonies than they did in the metropolis. Metropolitan institutions did not necessarily disappear in the process of settlement, but many were modified 
depending on the conditions of the particular settlement. Thus English New World colonies may have employed English law, and French colonies continued French legal institutions, but English and French temperate zone colonies differed in many important regards from the respective Caribbean colonies. French and English Caribbean colonies had greater similarities than they did with either their mainland counterparts or the metropolis. And, while the initial controls over free white labor may have been much the same in all of the colonies, only some English colonies and only some French colonies came to rely on free, rather than slave, labor. ${ }^{24}$ Climate and resources were the most powerful determinants of the geographic incidence of slave labor, irrespective of the metropolitan institutional structure. Slavery was legal in all the British colonies until the Revolutionary War, and differences in legal circumstances did not account for the significant differences in the relative importance of slavery in New England and the South. ${ }^{25}$

Another approach to the question of whether institutions are endogenous to the process of economic change, is to consider whether economic growth itself influences people's attitudes, and the nature of the economy's institutions. Does the economy itself contain the seeds of its own limitations, whether due to its failure or its successes? Karl Marx is certainly the most prominent of historical economists that have posited a sequence of self-generated endogenous changes in society, from feudalism to capitalism to socialism, with each of the first two stages being successful at first but then failing due to internal contradictions. Joseph Schumpeter claimed that the declining belief in the value of capitalism, which developed with economic growth, weakened capitalism's survival power, and he expected the "march into socialism" to occur based upon the 
economy's success. Mancur Olson argued that as economies develop over time, vested interests operating in their own self-interest emerge and cause a reduction in the future growth of the economy through their success at rent seeking. Other causes of selfgenerated changes in the economy and economic structures include the growth of large industry and the development of bureaucracies in business and government, both of which can force institutional changes.

Scholars interested in how institutions evolve have recently devoted much attention to the contrasts between colonial and metropolitan influences on institutions in newly settled areas. A long-standing disagreement, tracing back centuries, regarding the thirteen colonies that became the United States has been the causes of North-South differences in economic and demographic structures, including the explanation of the differences in the relative importance of slavery. Did those settling in different parts of the mainland arrive with rather different cultural patterns from Britain, differences that persisted after settlement, or did the various colonists from Britain arrive with basically similar cultural beliefs, but then adjusted their institutions once established in the New World and confronted with a rather different set of conditions? ${ }^{26}$ The evidence to date seems to favor the latter view. Not only has recent work demonstrated that even the Puritans were deeply influenced by the environment in selecting institutions for their two New World colonies, but studies of those Englishmen who came to populate the various settlements in the Americas emphasize how they were drawn from roughly the same social classes. ${ }^{27}$ In the words of Edward Channing:

"Historical writers have been altogether too prone to draw a hard and fast line of demarcation between the settlers of the Southern colonies and those who founded colonies north of the fortieth parallel ... It is sometimes said that the Northern colonist came to the New World for conscience sake and the Southern planters 
sought wealth alone; but no such generalization can truthfully be made. Moreover, it is oftentimes the custom to point out some mysterious differences between the Virginian and the New Englander, which can be expressed by the words 'cavalier' and 'Puritan' ... No such characterization is possible." 28

This perspective receives strong support from the record of slavery in the Americas. The basis for the success (to the owners) of slave labor in one area, and its failure in another, depended less on the initial attitudes of most settlers than upon the influence of climate and soil resources on the nature of those crops which could be grown and the technology and scales of efficient crop production. Wherever the soils and climates were suitable for growing sugar, the most valuable commodity in world trade during the $17^{\text {th }}$ and $18^{\text {th }}$ centuries and a crop that could be produced at lowest cost on large slave plantations (under the gang labor system, which allowed owners to achieve very high labor intensity), slavery became the dominant institution of labor (and those of African descent a dominant share of the population). Elsewhere, where soils and climates favored agricultural products, such as grains and hays, where the gang labor system and slave labor offered no particular advantages, landowners had to rely more on free (often their own) labor, as the productivity of slaves in such settings would not warrant the high prices for slaves that prevailed on world markets. The populations of these settlements accordingly came to be much more homogeneous in wealth, human capital, ethnicity, and other dimensions. Thus, the factor endowments in the various colonies had a major impact on determining which labor institutions were dominant, the distribution of rewards between laborers and landowners, and the nature of political participation and decision-making. Because slavery was legal in all of the European colonies in the Americas, it is evident that not only did these natural forces lead to 
differences in institutions, but they also led to different outcomes from similar institutions. Although the Old World background was surely important, it is difficult to explain the extreme differences among the various areas within each colonial empire without reference to the effects of the New World circumstances.

The early history of the New World colonies established by the European nations permits one to examine some of the implications of focusing on exogenous factors in institutional development, as opposed to viewing institutions as largely endogenous. The locations of settlements were themselves subject to some choice, based on the demographic and economic characteristics of different locations. Moreover, the pattern of initial settlement was modified over time, as settlers learned more about prospects in different areas. In the settlement of the Caribbean by the British and the French, for example, the adjustments in terms of crops and labor institutions that took place over the first half-century of settlement were rather different from those that were to emerge in subsequent years. The problems that arise from selection by the colonizing powers notwithstanding, the natural experiment arising from the variety of settling metropolises including Spain, Portugal, Britain, France, and Holland - and the extreme diversity of environments found among the colonies makes for a wonderful laboratory in which to study the relationships between factor endowments, institutions, and economic growth. It should not be surprising that many scholars have been attracted to work in this laboratory. Their work, of course, does not amount to a comparison of institutional and non-institutional factors in economic growth, since everyone agrees on the importance of institutions. Rather the work has sought to determine whether institutions can be understood as exogenous to the circumstances or economic system, or whether the 
environment or circumstances more broadly exert a powerful influence on how institutions emerge and evolve over time. Put simply, where do institutions come from?

A key economic question is the explanation for the post-1900 differences in levels of per capita income between the countries of mainland North America and those of Latin America (Table 3), differences that were much smaller during the colonial period. A closely related issue is why Latin America is the region of the world today with the most extreme inequality in income. Since the nations of South and Central America had been settled mainly by the Spanish (the Portuguese settled Brazil), and the United States and Canada mainly by the British (pre-1763 Canada by the French and pre-1664 New York by the Dutch, among the relatively less dominant settling nations), the traditional, and still popular, explanation holds that the different cultures, religions, and institutions of Britain and Spain could alone explain the divergent paths of economic development. Since there were sharp contrasts between the home countries of Britain and Spain in terms of economic and political structures, it is argued that the transfer of Old World institutions established the behavior of the economies and societies of the colonies in the New World, as differences in property rights determination and enforcement, legal frameworks more generally, economic goals, and in religions beliefs were thought to have been carried over, with little or no modification, into the new areas of settlement. The institutions that failed to generate sustained economic growth on the Iberian peninsula likewise failed to do so in the New World, whereas the institutions that had evolved over centuries in Britain worked on both sides of the Atlantic. The logic is that either the political elites of the metropolis were carried over into the colonies, providing the political and legal framework for the successful carryover of institutions, or that the 
elites in the New World, though different from those of the metropolis, were able to use the same institutional structures to achieve similar ends by similar means. ${ }^{29}$

An alternative explanation, one that has gained an increasing number of adherents of late, focuses on the economic and geographic circumstances in the area of settlement, and their influence on the determination of institutions in the new areas. As with the previous argument, there is a long literature on the role of climate and resources in influencing institutions and economic development. While a most detailed examination was provided by Montesquieu in the 1740 's, a similar argument was made considerably earlier by Plato. ${ }^{30}$ The links include the nature of the effects of climate upon the willingness to work, the desire to emigrate or immigrate, the role played by slavery in society, and related economic concerns. Whether seen as the basic cause of the specific set of institutions, or as a reason to modify some pre-existing set of exogenous institutions, settlement societies can be argued to have been significantly influenced by factors other than some unchanged metropolitan institutions. Indeed most settlements made dramatic changes in their institutions after they were first established, in the search for ways to enhance their profitability and survivability. The impact of climate and resources can also help to explain why the different areas settled by the same metropolitan power had rather different economic structures and performances (as, e.g., New England and the British West Indies), and why geographically contiguous and resource-similar areas settled by different metropolitan powers (as the British and French in the West Indies, as well as the Spanish, Danish, and Dutch there) came to resemble each other in many important ways. Indeed, recent scholarship has found strong evidence of the systematic effects of initial factor endowments on the types of institutions 
(including institutions involving suffrage and the conduct of elections, schooling, finance, the disposition of public lands, property rights, and intellectual property) that evolved in different colonies (and on long-term economic performance in these colonies), both in the Americas and elsewhere, and highlighted how limited is the explanatory power of national heritage. ${ }^{31}$

A specific example of how institutions can be altered to fit changing circumstances, and of how the distribution of power (both political and economic) as well as the environment influence outcomes, is provided by the adjustments in the societies of the Americas to the abolition of slavery. ${ }^{32}$ This most dramatic institutional change of the $19^{\text {th }}$ century was, almost everywhere, imposed on a resistant slaveholding class in the aftermath of armed conflict or by a government elected by a population dominated by non-slaveholders (including European parliaments). All New World societies ended slavery between 1777 and 1888, and the nature of the abolitions were similar with most providing some form of compensation, in cash, bonds, or labor time to the slaveowners, with very little or nothing going to the former slaves. ${ }^{33}$ Nevertheless there were some striking differences in the range of post-emancipation responses. In the British West Indies, for example, slavery was abolished by 1834 and all colonial governments had the same basic goal of inducing labor to work on plantations and imposed legislation to try to accomplish this end. Different environments led to different outcomes, however, as evident in the corresponding variation with the ratio of land to labor (see Table 4). ${ }^{34}$ Areas of high population density such as Barbados maintained plantation systems and high sugar output, while those with low population density, with abundant frontier land, initially saw the end of the plantation system and a decline in sugar output. In those cases 
where the islands had been relatively unproductive, sugar output continued to decline and the plantation system was never re-introduced. However, in those areas where land was highly productive and which had been growing rapidly before emancipation (such as Trinidad and British Guiana), plantation systems returned in several decades, but ones based on indentured labor drawn mainly from India, and not on ex-slaves. Thus the elite's ability to achieve their desired end, extracting the returns to the land they owned, was influenced by various other conditions, including resource endowments, and their efforts to achieve their goals, subject to the dissimilar constraints they faced, led to differences in institutional development.

Another example of how the evolution of institutions across New World societies reflected adjustments to different or changed circumstances is provided by the history of how broadly the franchise was extended over time and what fractions of respective populations actually voted in elections. Since most of the societies in the Americas had achieved independence from their colonial masters, and were at least nominal democracies, by the middle of the $19^{\text {th }}$ century, suffrage institutions had a direct bearing on the extent to which elites based largely on wealth, human capital, and gender held disproportionate political power in their respective countries, and on their ability to shape government policies. The ability and inclination of the elites to maintain disproportionate political influence through the formal rules associated with the electoral process varied with a variety of circumstances. Among these circumstances was the extent of inequality in wealth, human capital, and political influence that existed at the time of independence, when there were generally conventions held to draw up constitutions for the new nations. Presumably, the greater the disparity in resources (which we have argued in other work 
was due to factor endowments during initial colonization), the greater was the ability of an elite to frame the rules in such a way as to preserve their relative political power. ${ }^{35}$ Among the other factors that appear to have had significant effects on the way institutions evolved, however, was the relative scarcity of labor. Although elites may generally be reluctant to share their access to political influence and economic opportunity with other segments of the population, they should be more likely to do so in settings where they would benefit from attracting or retaining a scarce resource - labor.

The evidence on the evolution of suffrage institutions in the New World is quite consistent with this view. Summary information on how the right to vote was restricted across New World societies in the $19^{\text {th }}$ and early $20^{\text {th }}$ centuries is reported in Table 5. The estimates reveal that the United States and Canada were the clear leaders in doing away with restrictions based on wealth and literacy and introducing the secret ballot, and much higher fractions of the populations voted in these countries than anywhere else in the Americas. These societies were distinguished for their relative equality, population homogeneity, and scarcity of labor, and it is notable that others of British heritage, such as Barbados, generally retained stringent restrictions on the franchise well into the $20^{\text {th }}$ century. Moreover, it is striking that the leaders in extending the suffrage in South and Central America, such as Uruguay, Argentina, and Costa Rica, are generally regarded as having been historically the most egalitarian of Latin American societies, and having initial factor endowments most closely resembling those of the United States and Canada.

The contrast between North and South America in the application of binding restrictions on the franchise was not so evident at the outset. Despite the sentiments popularly attributed to the Founding Fathers, voting in the United States was largely a 
privilege reserved for white men with significant amounts of property until early in the nineteenth century. By 1815 , only four states had adopted universal white male suffrage, but as the movement to do away with political inequality gained strength, the rest of the country followed suit: virtually all new entrants to the Union extended voting rights to all white men (with explicit racial restrictions generally introduced in the same state constitutions that did away with economic requirements), and older states revised their laws in the wake of protracted political debates (see Table 6). The key states of New York and Massachusetts made the break with wealth restrictions in the $1820 \mathrm{~s}$, and the shift to full white adult male suffrage was largely complete by the late 1850s (with Rhode Island, Virginia, and North Carolina being the laggards). The relatively more egalitarian populations of the western states, which were anxious to increase their populations, were the clear leaders in the movement. The rapid extension of access to the franchise in these areas not coincidentally paralleled liberal policies toward public schools and access to land, as well as other policies that were expected to be attractive to potential migrants. The frontier states in the West continued to be labor scarce, with low female to male ratios, and it is perhaps not surprising that late in the $19^{\text {th }}$ century they were the leaders in extending suffrage to women, as well as in greatly strengthening the property rights available to married women.

Similar political movements with similar outcomes followed with a short lag in the various Canadian provinces, but the analogous developments did not occur in Latin America until the twentieth century. As a result, through 1940 the United States and Canada routinely had proportions voting that were 50 to 100 percent higher than their most progressive neighbors to the South, three times higher than Mexico, and up to five 
to ten times higher than countries such as Brazil, Bolivia, Ecuador, and even Chile. It is remarkable that as late as 1900, none of the countries in Latin America had the secret ballot or more than a miniscule fraction of the population casting votes. The great majority of European nations, as well as the United States and Canada, achieved secrecy in balloting and universal adult male suffrage long before other countries in the western hemisphere, and the proportions of the populations voting in the former were always higher, often four to five times higher, than those in the latter. Although many factors may have contributed to the low levels of participation in South America and the Caribbean, wealth and literacy requirements were serious binding constraints.

What accounts for this pattern of diffusion of universal male suffrage across New World societies? One obvious explanation is that differences in the degrees of inequality in wealth, human capital, and political influence were related to the likelihood of adopting such an institutional change. The cross-sectional patterns, as well as the histories indicating that the attainment of universal male suffrage and of the secret ballot was often the product of a long series of hard fought political battles, with the elites more likely to be opposed to liberalizing the franchise, are certainly consistent with this view. ${ }^{36}$ Another important factor, however, was the desire to attract immigrants. It is striking that pioneers in extending suffrage, such as new (those after the original thirteen) states in the United States, Argentina, and Uruguay, did so during periods in which they hoped to attract migrants, such that the rights to suffrage formed part of a package of policies thought to be potentially attractive to those contemplating relocation. When elites -- such as large holders of land or other assets -- desire common men to locate in the polity, they thus may choose to extend access to privileges and opportunities without threat of civil 
disorder; indeed, a polity (or one set of elites) may find itself competing with another to attract the labor or whatever else is desired. Alternative explanations, such as the importance of national heritage, are not very useful in identifying why Argentina, Uruguay, and Costa Rica pulled so far ahead of their Latin American neighbors, or why other British colonies in the New World lagged behind Canada. ${ }^{37}$

\section{V.}

There are always institutions present, and we cannot conceive of a framework for making sense of the processes of economic development that does not include a role for them. There is, moreover, no doubt that for any given society some institutions may limit the extent to which it realizes its potential economic output, while alternatives might do better. That being said, however, it is unclear how firmly theories of economic growth can be grounded on institutions. Economists do not have a very good understanding of where institutions come from, or why some societies have institutions that seem conducive to growth, while others are burdened by institutions less favorable for economic performance. Until they do, it will be quite difficult to specify the precise role of institutions in processes of growth.

As we have sought to highlight in this essay, what little we presently know about the evolution of institutions suggests caution about making strong claims about their relationship to growth. First, it is clear that very different institutional structures often seem to be reasonable substitutes in being conducive to growth, both in dissimilar as well as in similar contexts. Narrow definitions of institutional requirements for growth do not, accordingly, seem appropriate. Second, the case for attributing growth to institutions is 
weaker if institutions are endogenous rather than exogenous, and the evidence that there are systematic patterns to the ways institutions evolve makes the latter view problematic. The recent studies of the natural experiment in institutional development provided by the European colonization of the Americas (and of many other parts of the globe), for example, imply that the broad environment (reflecting factor endowments, social arrangements, or technology) had powerful effects on the sorts of institutions that evolved in respective colonies. Institutions obviously matter for growth, but the way we understand how they matter will be somewhat different if the agents and other forces shaping institutions are responsive to the conditions they face than if institutions develop independently of (or could be imposed in any) context.

The recognitions that the institutional structure appropriate for one environment may not be appropriate for another, and that the history of institutions in high-performing societies is one of change over time in response to changing circumstances, suggest a different perspective on the relation between institutions and growth. Although we all understand that there are favorable aspects to governments making credible commitments to various obligations or arrangements they enter into, such as enforcement of property rights, it is also clear that in theory one would want institutions to vary over time and place with the environment, technology, and values. One might, therefore, think of societies with institutions conducive for growth as being those that have exhibited greater institutional flexibility -- where by institutional flexibility we mean the ease with which institutional adaptations that respond constructively to changes in circumstances are innovated and/or diffused. Societies with good institutions would, therefore, have institutions well adapted for economic performance in their specific settings because they 
had implemented a series of institutional modifications or innovations (public and private) that cumulatively generated improvements in welfare. Societies with bad institutions are those with institutional inflexibility, whose institutions did not respond constructively to take advantage of the opportunities created by their environment and state of knowledge. Such a framework would encourage scholars interested in the relation between institutions and growth to devote more attention to the factors influencing the rate and direction of institutional change, and rather less attention to the quest for a set of institutional structures that would be universally effective at promoting growth. 


\section{ENDNOTES}

${ }^{1}$ Among a vast literature, see North and Thomas 1973; North 1981; Rosenberg and Birdzell 1986; Jones 1987; Landes 1998; Engerman and Sokoloff 1997 and 2002; Pomeranz 2000; Acemoglu, Johnson, and Robinson 2001 and 2002; and Easterly and Levine 2003. For even earlier discussions, see Weber 1958 and 1961; and Sombart 1969.

${ }^{2}$ See, for example, Hartwell 1971.

${ }^{3}$ Early $20^{\text {th }}$ century scholars, such as Weber (1958 and 1961), emphasized the role of culture, but the focus turned to real economic factors by the second half of the century. For a more extensive discussion of how thinking changed over time, see Arndt 1978 and 1987.

${ }^{4}$ On the role of coal, see Kindleberger 1961, and the discussion by Parker in the same volume. Although attention to the significance of coal waned, it has recently revived with Wrigley 1988 and Pomeranz 2000. For discussion of the relative importance of changes in savings rates, or in investment opportunities, see Postan 1935. For discussions of how the pace of technological change was responsive to economic factors, such as the extent of, or access to, markets, see Landes 1969 and Sokoloff 1988.

${ }^{5}$ See the discussion of non-conformists in Britain in Weber 1958; Sombart 1969; McClelland 1961; and Fogel 2000.

${ }^{6}$ See Steuart 1767; Gilboy 1932; Nef 1958; deVries 1994; and Jacob 1997.

${ }^{7}$ See, the discussions of different views in Berman 1983; Putnam 2002; and O’Brien 1988.

${ }^{8}$ Whereas Weber is well known for his theory of how the content of Protestant thought may have encouraged believers to behave in ways we associate with capitalism, Tawney highlighted how economic change supported change in religious beliefs. See Weber 1958 and Tawney 1926.

${ }^{9}$ For a recent restatement of how the immutability of culture can explain continued backwardness, see Landes 1998.

${ }^{10}$ For the linkage between morality and economics, see the discussion of Quakers and slavery in Smith 1979. Also see Fogel 1989.

${ }^{11}$ See the discussion of institutions, and the approaches of the British and Germans, in Cunningham 18901892.

${ }^{12}$ See North 1981, 1988, and 1990; North and Thomas 1973; North and Weingast 1989; and Davis and North 1971.

${ }^{13}$ For a classic treatment of how factor endowments can help to shape culture and institutions, see Tocqueville 1835. For interesting discussions of the influences of factor endowments and political forces, see Brenner 1985; Engerman and Sokoloff 1997 and 2002; North 1981 and 1990; and North, Weingast, and Summerhill 2000. 
${ }^{14}$ A major concern of the property rights literature is with private agents being secure from expropriation by the state. See North 1981; North and Weingast 1989; Knack and Keefer 1997; Acemoglu and Robinson 2000; and Haber, Razo, and Maurer 2003.

${ }^{15}$ Even Weber's discussion of the role of Calvinism points out that the relation "was true only when some possibility of capitalistic development in the areas in question was present." See Weber 1958, p. 190.

${ }^{16}$ North and Weingast 1989.

${ }^{17}$ In some cases of change there may be required compensation to be paid to those whose condition is weakened, requiring increased taxation of other members of the population. Nearly all serf and slavery systems that ended during the $19^{\text {th }}$ century did so with compensation paid to property holders, not laborers, but there was no compensation of losers when the slave trade was ended.

${ }^{18}$ See the discussions in Elbaum and Lazonick 1986.

19 Thus, as suggested by Lance Davis and North, evaluating institutional change may be subject to the same type of benefit-cost analysis as are other economic factors. See Davis and North 1971.

${ }^{20}$ See the discussions of the evolution of restrictions on suffrage in Engerman and Sokoloff 2001; and Keyssar 2000.

${ }^{21}$ Of course, other conditions matter as well. Where there is extreme economic inequality, for example, an elite might be able to leverage its wealth into disproportionate political influence through informal channels. Another example of context mattering is where labor is scarce, such as on a frontier. The desire of an elite, even one with a monopoly on political voice, to attract migrants might lead to policies that groups that have no formal representation value. For a discussion of how this might have operated on the U.S. frontier, see Engerman and Sokoloff 2001.

${ }^{22}$ In most cases, we would expect that groups with no formal political influence would have quite circumscribed access to scarce resources. This limited access might be due to the laws explicitly favoring the dominant groups, even if the property rights allowed the "outsiders" were enforceable. A de facto limited access might, however, arise if the outside group lacked the financial or other resources necessary to take advantage of an opportunity they had a de jure legal right too. Thus, even though all citizens might be entitled to bring civil suits to enforce contracts, the poor may find themselves less able to act on this right. The case of married women is an interesting one to consider in this regard, as in the United States (and many other countries) the law allowed them only very limited rights as to owning property or entering into contracts as compared to those allowed men or single women, until the second half of the $19^{\text {th }}$ century. See Khan 1996.

${ }^{23}$ See Engerman and Sokoloff 1997 and 2002; Acemoglu, Johnson, and Robinson 2001 and 2002; and Easterly and Levine 2003.

${ }^{24}$ For an interesting analysis of adjustments to the laws governing slavery, see Cottrell 2001.

${ }^{25}$ For a discussion of the fascinating case of how a colony established with a prohibition on slavery came to have it lifted, see Wood 1984.

${ }^{26}$ See, for example, Greene 1988, 1993, and 2002; and Fischer 1989.

${ }^{27}$ Kupperman 1993.

${ }^{28}$ Channing 1926, pp. 145-146. 
${ }^{29}$ It may be, however, that the distance between colony and homeland weakens the ability of the metropolis to control the settlers, weakening the nature of any transfer of political structure. See Greene 1988 and 2002. For the argument that the institutional heritage that British colonies drew on was more conducive to long-run growth than that the Spanish colonies worked from, see North 1988.

${ }^{30}$ See Montesquieu 1949; and Plato 1980, book five, section nine.

${ }^{31}$ There is some question of what the comparison of institutions would indicate if some different dates were used for the evaluation. Spain arrived in America earlier than the British, went to areas with greater wealth and resources, and it took about another hundred years before the British arrived and were forced to go to areas that they regarded as clearly less promising for economic growth. For a comparison based on the year 1700 we would find the Spanish position seemingly more favorable that that of the British, reflecting the early economic advantages of the areas of Spanish settlement, and, as pointed out by John TePaske, the Spanish had three successful centuries in the Americans, and the British only two. See Te Paske 2002. Also see Engerman and Sokoloff 1997 and 2002; Acemoglu, Johnson and Robinson 2002; and Easterly and Levine 2003.

${ }^{32}$ The recent literature on the role of institutions in economic growth has raised important questions as to the extent to which political power is independent of economic power, and to the relative significance of political inequality and economic inequality for how institutions evolve. A full discussion of these issues is beyond the scope of this essay, but we would argue that although they are clearly related, and there is certainly an association across societies (or over time) between political power and economic power, the correlation is far from perfect and it is not all that uncommon for them to diverge. Their relative weight in the processes of institutional development likely varies with context. Moreover, some institutions may be more sensitive to political inequality, while others depend more on the extent of economic inequality. For example, the distribution of political influence would generally be expected to have a greater impact on public institutions, such as laws, and the distribution of wealth matter relatively more for the kinds of private institutions -- such as financial institutions - that evolve.

${ }^{33}$ The United States, in 1865, was the one nation to free its slaves without any form of compensation provided in the form of cash, apprenticeship, or a "law of the free womb", which required the free-born offspring of slaves to labor for the mother's master into their late teens or twenties. Even Haiti agreed to pay compensation to the French after 1825, as a condition for the right to engage in trade with France.

${ }^{34}$ See Engerman 1982 and 1996. For a classic treatment of the relationship between the land to labor ratio and institutions, see Domar 1970.

${ }^{35}$ For discussions of how factor endowments are the principal source of the differences in inequality, see Engerman and Sokoloff 1997 and 2002.

${ }^{36}$ The achievements of a broadening of the formal requirements for suffrage, as well as of the more administrative procedures governing the conduct of elections, tend to overstate the reduction in the extent of political inequality. Economic elites always enjoy disproportionate informal political influence, and there is likely more scope for them to bypass formal procedures and channels in contexts where there is extreme inequality. Hence, it may not be so surprising that the outcomes did not improve more than they did after the extension of the suffrage in many of the Latin American societies.

${ }^{37}$ For a fuller discussion of the issues involved in the evolution of suffrage institutions in the New World, see Engerman and Sokoloff 2001. Also see Acemoglu and Robinson 2000, for treatment of the somewhat different pattern in Europe. 


\section{BIBLIOGRAPHY}

Acemoglu, Daron and James A. Robinson. 2000. "Why Did Western Europe Extend the Franchise? Quarterly Journal of Economics 115 (Nov.): 1167-1199.

Acemoglu, Daron and Simon Johnson, and James A. Robinson. 2001. "The Colonial Origins of Comparative Development: An Empirical Investigation." American Economic Review 91 (Dec.): 1369-1401. . 2002. "Reversal of Fortune: Geography and Institutions in the Making of the Modern World Income Distribution, Quarterly Journal of Economics 117 (Nov.): 1231-1294.

Arndt, H.W. 1978. The Rise and Fall of Economic Growth: A Study in Contemporary Thought. Melbourne: Longman Cheshire.

University of Chicago Press.

1987. Economic Development: The History of an Idea. Chicago:

Berman, Harold J. 1983. Law and Revolution: The Formulation of the Western Legal Tradition. Cambridge, MA: Harvard University Press.

Brenner, Robert. 1985. “Agrarian Class Structure and Economic Development in PreIndustrial Europe." In T.H. Aston and C.H.E. Philpin, eds., The Brenner Debate: Agrarian Class Structure and Economic Development in Pre-Industrial Europe. Cambridge: Cambridge University Press.

Channing, Edward. 1926. A History of the United States: Volume I. New York: Macmillan.

Cottrell, Robert J. 2001. "The Long Lingering Shadow: Law, Liberalism, and Cultures of Racial Hierarchy and Identity in the Americas.” Tulane Law Review 76 (1): 11-79.

Cunningham, William. 1890-1892 [1882]. The Growth of English Industry and Commerce. 2 vols. Second Edition. Cambridge: Cambridge University Press.

Davis, Lance E. and Douglass C. North. 1971. Institutional Change and American Economic Growth. Cambridge: Cambridge University Press.

De Vries, Jan. 1994. “The Industrial Revolution and the Industrious Revolution.” Journal of Economic History 54 (June): 249-270.

Domar, Evsey D. 1970. "The Causes of Slavery or Serfdom: A Hypothesis.” Journal of Economic History 30 (March): 18-32.

Easterly, William and Ross Levine. 2003. "Tropics, Germs, and Crops: The Role of Endowments in Economic Development." Journal of Monetary Economics 50 (Jan): 339. 
Elbaum, Bernard and William Lazonick. 1986. The Decline of the British Economy. Oxford: Clarendon Press.

Engerman, Stanley L. 1982. "Economic Adjustments to Emancipation in the United States and the British West Indies." Journal of Interdisciplinary History 12 (Autumn): 191-220.

. 1996. "The Land and Labour Problem at the Time of the Legal Emancipation of the West Indian Slaves." In Roderick A. McDonald, ed., West Indies Accounts: Essays in the History of the British Caribbean and the Atlantic Economy in Honor of Richard Sheridan. Kingston: University of West Indies Press.

Engerman, Stanley L., Stephen Haber, and Kenneth L. Sokoloff. 2000. "Inequality, Institutions, and Differential Paths of Growth Among New World Economies." In Claude Menard, ed., Institutions, Contracts, and Organizations. Cheltenham: Edward Elgar.

Engerman, Stanley L. and Kenneth L. Sokoloff. 1997. "Factor Endowments, Institutions, and Differential Paths of Growth Among New World Economies: A View from Economic Historians of the United States." In Stephen Haber, ed., How Latin America Fell Behind. Stanford: Stanford University Press.

. 2001. "The Evolution of Suffrage Institutions in the Americas." Working Paper 8512. Cambridge, MA: National Bureau of Economic Research. . 2002. "Factor Endowments, Inequality and Paths of Development Among New World Economies.” Economia 3 (Fall): 41-109.

Fischer, David Hacket. 1989. Albion's Seed: Four British Folkways in America. New York: Oxford University Press.

Fogel, Robert William. 1989. Without Consent or Contract. New York: W. W. Norton. . 2000. The Fourth Great Awakening \& The Future of Egalitarianism. Chicago: University of Chicago Press.

Gilboy, Elizabeth. 1932. "Demand As a Factor in the Industrial Revolution.” In Facts and Factors in Economic History: Articles by Former Students of Edwin Francis Gay. Cambridge, MA: Harvard University Press.

Greene, Jack P. 1988. Pursuits of Happiness. Chapel Hill: University of North Carolina Press.

1993. The Intellectual Construction of America: Exceptionalism and Identity from 1492 to 1800 . Chapel Hill: University of North Carolina Press.

. 2002. "Transatlantic Colonization and the Redefinition of Empire in the Early Modern Era: The British-America Experience.” In Christine Daniels and Michael V. Kennedy, eds., Negotiated Empires: Centers and Peripheries in the Americas, 15001820. New York: Routledge.

Haber, Stephen, Armando Razo, and Noel Maurer. 2003. The Politics of Property

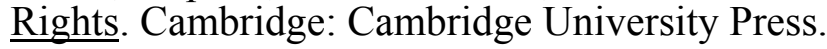


Hartwell, R.M. 1971. The Industrial Revolution and Economic Growth. London: Methuen.

Jacob, Margaret C. 1997. Scientific Culture and the Making of the Industrial West. New York: Oxford University Press.

Jones, E. L.. 1987. The European Miracle: Environments, Economics, and Geopolitics in the History of Europe and Asia. Cambridge: Cambridge University Press.

Keyssar, Alexander. 2000. The Right To Vote: The Contested History of Democracy in the United States. New York: Basic Books.

Khan, B. Zorina. 1996. “Married Women's Property Laws and Female Commercial Activity." Journal of Economic History 56 (June): 356-388.

Kindleberger, Charles P. 1961. "International Trade and Investment and Resource Use in Economic Growth" and William N. Parker, "Comment." In Joseph J. Spengler, ed., National Resources and Economic Growth. Washington, D.C.: Resources for the Future.

Knack, Stephen and Philip Keefer. 1997. "Does Social Capital Have an Economic Payoff." Quarterly Journal of Economics 112 (Nov.): 1251-1288.

Kupperman, Karen Ordahl. 1993. Providence Island. 1630-1641: The Other Puritan Colony. Cambridge.

Landes, David S. 1969. The Unbound Prometheus. Cambridge: Cambridge University Press. 1998. The Wealth and Poverty of Nations: Why Some Are So Rich and Others So Poor. New York: W.W. Norton.

McClelland, David C. 1961. The Achieving Society. Princeton: Van Nostrand.

Maddison, Angus. 2001. The World Economy: A Millennial Perspective. Paris: OECD.

Merton, Robert K. 1970 [1938]. Science, Technology and Society in Seventeenth Century England. New York: Harper \& Row.

Montesquieu, Charles de Secondat, baron de. 1949 [1748]. The Spirit of the Laws. New York: Hafner Press.

Nef, John U. 1958. Cultural Foundations of Industrial Civilization. Cambridge: Cambridge University Press.

North, Douglass C. 1981. Structure and Change in Economic History. New York. . 1988. "Institutions, Economic Growth and Freedom: An Historical Introduction." In Michael Walker, ed., Freedom, Democracy, and Economic Welfare. Vancouver. 1990. Institutions, Institutional Change and Economic Performance. Cambridge: Cambridge University Press. 
North, Douglass C. and Robert P. Thomas. 1973. The Rise of the Western World: A New Economic History. Cambridge: Cambridge University Press.

North, Douglass C. and Barry Weingast. 1989. "Constitutions and Commitment: The Evolution of Institutions Governing Public Choice in Seventeenth-Century England." Journal of Economic History 49 (December): 803-832.

North, Douglass C., William Summerhill, and Barry Weingast. 2000. “Order, Disorder, and Economic Change: Latin America Versus North America." In Bruce Bueno de Mesquita and Hilton L. Root, eds., Governing for Prosperity. New Haven: Yale University Press.

O'Brien, Patrick K. 1988. "The Political Economy of British Taxation, 1660-1815". Economic History Review 41 (February): 1-32.

Plato. 1980. Laws. New York: Basic Books.

Pomeranz, Kenneth. 2000. The Great Divergence: Europe, China, and the Making of the Modern World Economy. Princeton: Princeton University Press.

Postan, M.M. 1935. "Recent Trends in the Accumulation of Capital.” Economic History Review 6 (October): 1-12.

Putnam, Robert D., ed., 2002. Democracies in Flux: The Evolution of Social Capital in Contemporary Society. Oxford: Oxford University Press.

Rosenberg, Nathan and L.E. Birdzell, Jr. 1986. How the West Grew Rich: The Economic Transformation of the Industrial World. New York: Basic Books.

Smith, Adam. 1979 [1776]. Inquiry into the Nature and Causes of the Wealth of Nations. Oxford: Clarendon Press.

Sokoloff, Kenneth L. 1988. "Inventive Activity in Early Industrial America: Evidence from Patent Records, 1790-1846." Journal of Economic History 48 (Dec.): 813-850.

Sokoloff, Kenneth L. and Stanley L. Engerman. 2000. "Institutions, Factor Endowments, and Paths of Development in the New World." Journal of Economic Perspectives 14 (Summer 2000): 217-232.

Sombart, Werner. 1969 [1913]. The Jews and Modern Capitalism. New York: Burt Franklin.

Steuart, James Sir. 1767. An Inquiry Into the Principles of Political Economy. London: A. Millar and T. Cadell.

Tawney, R. H. 1926. Religion and the Rise of Capitalism: A Historical Study. New York: Harcourt, Brace and World. 
TePaske, John Jay. 2002. "The Vital Peripheries of Colonial South America." In Christine Daniels and Michael V. Kennedy, eds., Negotiated Empires: Centers and Peripheries in the Americas, 1500-1820. New York: Routledge.

Tocqueville, Alexis de. 1969 [1835]. Democracy in America. Translated by George Lawrence and Edited by J.P. Mayer. Garden City: Doubleday.

Weber, Max. 1958 [1905-6]. The Protestant Ethic and the Spirit of Capitalism. New York: Scribner's. 1961 [1927]. General Economic History. New York: Collier Books.

Wood, Betty. 1984. Slavery in Colonial Georgia, 1730-1775. Athens.

Wrigley, E.A. 1988. Continuity, Chance, and Change. Cambridge: Cambridge University Press. 


\section{Table 1}

Levels Of Per Capita GDP And Interregional Differences, 1500-1998

(1990 international dollars)

\begin{tabular}{|c|c|c|c|c|c|c|c|}
\hline & 1500 & 1820 & 1870 & 1913 & 1950 & 1973 & 1998 \\
\hline Western Europe & 774 & 1232 & 1974 & 3473 & 4594 & 11534 & 17921 \\
\hline Western Offshoots & 400 & 1201 & 2431 & 5257 & 9288 & 16172 & 26146 \\
\hline Japan & 500 & 669 & 737 & 1387 & 1926 & 11439 & 20413 \\
\hline Asia (excl. Japan) & 572 & 575 & 543 & 640 & 635 & 1231 & 2936 \\
\hline Latin America & 416 & 665 & 698 & 1511 & 2554 & 4531 & 5795 \\
\hline Eastern Europe & 483 & 667 & 917 & 1501 & 2601 & 5729 & 4354 \\
\hline Africa & 400 & 418 & 444 & 585 & 852 & 1365 & 1368 \\
\hline World & 565 & 667 & 867 & 1510 & 2114 & 4104 & 5709 \\
\hline Interregional Spreads & $2: 1$ & $3: 1$ & $5: 1$ & $9: 1$ & $15: 1$ & $13: 1$ & $19: 1$ \\
\hline
\end{tabular}

Source: Maddison 2001. 
TABLE 2

Per Capita GDP In Western Europe, 1500-1998

(1990 international dollars)

\begin{tabular}{|c|c|c|c|c|c|c|c|}
\hline & 1500 & 1600 & 1700 & 1820 & 1870 & 1913 & 1998 \\
\hline Austria & 707 & 837 & 993 & 1218 & 1863 & 3465 & 18905 \\
\hline Belgium & 875 & 976 & 1144 & 1319 & 2697 & 4220 & 19442 \\
\hline Denmark & 738 & 875 & 1039 & 1274 & 2003 & 3912 & 22123 \\
\hline Finland & 453 & 538 & 638 & 781 & 1140 & 2111 & 18324 \\
\hline France & 727 & 841 & 986 & 1230 & 1876 & 3485 & 19558 \\
\hline Germany & 676 & 777 & 894 & 1058 & 1821 & 3648 & 17799 \\
\hline Italy & 1100 & 1100 & 1100 & 1117 & 1499 & 2564 & 17759 \\
\hline Netherlands & 754 & 1368 & 2110 & 1821 & 2753 & 4049 & 20224 \\
\hline Norway & 640 & 760 & 900 & 1104 & 1432 & 2501 & 23660 \\
\hline Portugal & 632 & 773 & 854 & 963 & 997 & 1244 & 12929 \\
\hline Spain & 698 & 900 & 900 & 1063 & 1376 & 2255 & 14227 \\
\hline Sweden & 695 & 824 & 977 & 1198 & 1664 & 3096 & 18685 \\
\hline Switzerland & 742 & 880 & 1044 & 1280 & 2202 & 4266 & 21367 \\
\hline United Kingdom & 714 & 974 & 1250 & 1707 & 3191 & 4921 & 18714 \\
\hline Total Western Europe & 774 & 894 & 1024 & 1232 & 1974 & 3473 & 17921 \\
\hline World & 565 & 593 & 615 & 667 & 867 & 1510 & 5709 \\
\hline
\end{tabular}

Source: Maddison 2001. 
TABLE 3

Per Capita Gross Domestic Product In Selected New World Economies, 1700-1997

\begin{tabular}{|c|c|c|c|c|}
\hline \multirow[b]{2}{*}{ Country } & \multirow[b]{2}{*}{1700} & \multirow[b]{2}{*}{1800} & \multicolumn{2}{|r|}{$\begin{array}{l}\text { (i) GDP per } \\
\text { capita relative } \\
\text { to the United } \\
\text { States }\end{array}$} \\
\hline & & & 1900 & 1997 \\
\hline Argentina & - & 102 & 52 & 35 \\
\hline Barbados & 150 & - & - & 51 \\
\hline Brazil & - & 50 & 10 & 22 \\
\hline Chile & - & 46 & 38 & 42 \\
\hline Cuba & 167 & 112 & - & - \\
\hline Mexico & 89 & 50 & 35 & 28 \\
\hline Peru & - & 41 & 20 & 15 \\
\hline Canada & - & - & 67 & 76 \\
\hline United States $^{\mathrm{a}}$ & 550 & 807 & 3,859 & 20,230 \\
\hline
\end{tabular}

Source: Sokoloff and Engerman (2000).

a. U.S. per capita GDP is measured in 1985 dollars. 
TABLE 4

Land/Labor Ratios, Changes In Sugar Production In The British Slaves Colonies Prior To And After Emancipation, And Contract Labor Immigration

$\begin{array}{cccc}\text { Land/Labor } & \text { \% Change } & \text { Ratio of Sugar } & \text { Contract Labor } \\ \text { Ratio }^{1} & \text { in Annual } & \text { Production in } & \text { Immigration } \\ & \text { Sugar Prod. } & 1887-96 \text { to } & 1834-1918 \\ & 1824-33 \text { to } & 1839-46 & \text { (gross inflow) } \\ 1839-46 & & \end{array}$

\begin{tabular}{|c|c|c|c|c|}
\hline Antigua & 3.1 & $+8.7 \%$ & 1.5 & 2,600 \\
\hline Barbados & 1.7 & +5.5 & 3.5 & -- \\
\hline St. Kitts ${ }^{2}$ & 2.9 & +3.8 & 2.7 & 2,900 \\
\hline Nevis & 5.0 & -43.1 & (2) & (2) \\
\hline Trinidad & 47.7 & $+21.7^{3}$ & 3.0 & 157,700 \\
\hline British Guiana & 832.4 & -43.0 & 3.4 & 301,000 \\
\hline Mauritius & 8.0 & +54.3 & 3.1 & 451,800 \\
\hline Dominica & 16.3 & -6.4 & 0.7 & 6,000 \\
\hline St. Lucia & 15.5 & -21.8 & 1.7 & 5,200 \\
\hline Montserrat & 4.6 & -43.7 & 2.5 & -- \\
\hline St. Vincent & 5.7 & -47.5 & 0.7 & 5,600 \\
\hline Tobago & 8.8 & -47.5 & (3) & (3) \\
\hline Jamaica & 12.2 & -51.2 & 0.6 & 53,900 \\
\hline Grenada & 6.3 & -55.9 & 0.0 & 6,200 \\
\hline
\end{tabular}

Source: Engerman 1996.

\footnotetext{
${ }^{1}$ Square Miles per thousand total population, just prior to abolition.

${ }^{2}$ Nevis data merged with St. Kitts after 1882.
${ }^{3}$ Trinidad output did decline slightly after abolition, and it was not until 1845 that the 1834 level of output was regained. Tobago data merged with Trinidad after 1891. The 1877-86 level of sugar production in Tobago was about one-third less than it was in 1824-33.




\section{TABLE 5}

Laws Governing the Franchise and the Extent of Voting in Selected New World Countries, 1840-1940

\begin{tabular}{|c|c|c|c|c|}
\hline Year & $\begin{array}{l}\text { Lack of Secrecy } \\
\text { in Voting }\end{array}$ & $\begin{array}{l}\text { Wealth } \\
\text { Requirement } \\
\text { For Franchise }\end{array}$ & $\begin{array}{c}\text { Literacy } \\
\text { Requirement for } \\
\text { Franchise }\end{array}$ & $\begin{array}{l}\text { Proportion of } \\
\text { Population } \\
\text { Voting }\end{array}$ \\
\hline
\end{tabular}

\begin{tabular}{|c|c|c|c|c|c|}
\hline 1840-80 & & & & & - \\
\hline Chile & 1869 & No & Yes & Yes & 1.6 \\
\hline & 1878 & No & No & $\mathrm{No}^{\mathrm{a}}$ & - \\
\hline Costa Rica & 1890 & Yes & Yes & Yes & - \\
\hline Ecuador & 1848 & Yes & Yes & Yes & 0.0 \\
\hline & 1856 & Yes & Yes & Yes & 0.1 \\
\hline Mexico & 1840 & Yes & Yes & Yes & - \\
\hline Peru & 1875 & Yes & Yes & Yes & - \\
\hline Uruguay & 1840 & Yes & Yes & Yes & - \\
\hline & 1880 & Yes & Yes & Yes & - \\
\hline Venezuela & 1840 & Yes & Yes & Yes & - \\
\hline & 1880 & Yes & Yes & Yes & - \\
\hline Canada & 1867 & Yes & Yes & No & 7.7 \\
\hline & 1878 & No & Yes & No & 12.9 \\
\hline United States & 1850 & No & No & No & 12.9 \\
\hline & 1880 & No & No & No & 18.3 \\
\hline 1881-1920 & & & & & \\
\hline Argentina & 1896 & Yes & Yes & Yes & $1.8^{\mathrm{b}}$ \\
\hline & 1916 & No & No & No & 9.0 \\
\hline Brazil & 1894 & Yes & Yes & Yes & 2.2 \\
\hline & 1914 & Yes & Yes & Yes & 2.4 \\
\hline Chile & 1881 & No & No & No & 3.1 \\
\hline & 1920 & No & No & Yes & 4.4 \\
\hline Colombia & $1918^{\mathrm{c}}$ & No & No & No & 6.9 \\
\hline Costa Rica & 1912 & Yes & Yes & Yes & - \\
\hline & 1919 & Yes & No & No & 10.6 \\
\hline Ecuador & 1888 & No & Yes & Yes & 2.8 \\
\hline & 1894 & No & No & Yes & 3.3 \\
\hline Mexico & 1920 & No & No & No & 8.6 \\
\hline Peru & 1920 & Yes & Yes & Yes & - \\
\hline Uruguay & 1900 & Yes & Yes & Yes & - \\
\hline & 1920 & No & No & No & 13.8 \\
\hline Venezuela & 1920 & Yes & Yes & Yes & - \\
\hline Canada & 1911 & No & No & No & 18.1 \\
\hline & 1917 & No & No & No & 20.5 \\
\hline United States & 1900 & No & No & Yes $^{\mathrm{d}}$ & 18.4 \\
\hline & 1920 & No & No & Yes & 25.1 \\
\hline
\end{tabular}


1921-40

\begin{tabular}{lccccc} 
Argentina & 1928 & No & No & No & 12.8 \\
Bolivia & 1937 & No & No & No & 15.0 \\
Brazil & 1951 & - & Yes & Yes & 4.1 \\
Colombia & 1930 & Yes & Yes & Yes & 5.7 \\
& 1930 & No & No & No & 11.1 \\
Chile & 1936 & No & No & No & 5.9 \\
& 1920 & No & No & Yes & 4.4 \\
Costa Rica & 1931 & No & No & Yes & 6.5 \\
Ecuador & 1938 & No & No & Yes & 9.4 \\
Mexico & 1940 & No & No & No & 17.6 \\
Peru & 1940 & No & No & Yes & 3.3 \\
Uruguay & 1940 & No & No & No & 11.8 \\
Venezuela & 1940 & No & No & Yes & - \\
& 1940 & No & No & No & 19.7 \\
Canada & 1940 & No & Yes & Yes & - \\
United States & & & & & \\
\hline
\end{tabular}

Source: Engerman, Haber, and Sokoloff (2000).

a. After having eliminated wealth and education requirements in 1878 , Chile instituted a literacy requirement in 1887, which seems to have been responsible for a sharp decline in the proportion of the population that was registered to vote.

b. This figure is for the city of Buenos Aires, and it likely overstates the proportion who voted at the national level.

c. The information on restrictions refers to national law. The 1863 Constitution empowered provincial state governments to regulate electoral affairs. Afterward, elections became restricted (in terms of the franchise for adult males) and indirect in some states. It was not until 1948 that a national law established universal adult male suffrage throughout the country. This pattern was followed in other Latin American countries, as it was in the United States and Canada to a lesser extent.

d. Eighteen states introduced literacy requirements between 1890 and 1926. 
TABLE 6

Summary Of Economic-Based Qualifications For Suffrage

Across The United States, 1787-1860

Qualification in 1787

Year Economic Qualifications

or Year of Entry $\quad$ Ended, or Qualif. in 1860

\section{Original Thirteen}

New Hampshire

Tax

1792

Massachusetts

Property

Rhode Island

Property

Connecticut

Property

New York

Property

New Jersey

Pennsylvania

Property

Delaware

Tax

Property

Maryland

Virginia

Property

North Carolina

Property

South Carolina

Property

Tax

Georgia

Property

1821 (prop), tax req. in 1860

1842 (prop), tax req. in 1860

1818 (prop), 1845 (tax)

1821 (prop), 1826 (tax)

1807 (prop), 1844 (tax) tax req. in 1860

1792 (prop), tax req. in 1860 1802

1850

1856 (prop), tax req. in 1860

1810 (tax)

1789 (prop), 1798 (tax)

\section{$\underline{\text { New States }}$}

Vermont

Kentucky

Tennessee

Ohio

Louisiana

Indiana

Mississippi

Illinois

Maine

Alabama

Missouri none (1791)

none (1792)

none (1796)

Tax (1803)

$\operatorname{Tax}(1812)$

none (1816)

Tax (1817)

none (1818)

none (1819)

none (1819)

none (1820) $1851(\operatorname{tax})$

$1845(\operatorname{tax})$

$1832(\operatorname{tax})$

Sources and Notes: Engerman and Sokoloff 2001. 